Journal of Health Promotion and Behavior (2017), 2 (2): 98-111

https://doi.org/10.26911/thejhpb.2017.02.02.01

\title{
Effect of Personal Factors, Family Support, Pocket Money, and Peer Group, on Smoking Behavior in Adolescents in Surakarta, Central Java
}

\author{
Ardiansyah Pandayu'), Bhisma Murti'), Pawito²) \\ 1) Masters Program in Public Health, Sebelas Maret University, Surakarta \\ 2)Faculty of Social and Political Sciences, Sebelas Maret University, Surakarta
}

\begin{abstract}
Background: According to WHO and Global Youth Tobacco Survey, Indonesia is the third largest country with current smokers in the world, including young smokers. It is widely known that smoking is hazardous to health and detrimental to economy. Surakarta is one of the major cities in Central Java where the prevalence of current smokers has been increasing among adolescents. This study aimed to determine the effect of personal factors, family support, pocket money, and peer group, on smoking behavior in adolescents in Surakarta, Central Java.

Subjects and Method: This was an analytic observational study using cross-sectional design. This study was carried out in 5 sub-districts in Surakarta, Central java, from February to March 2017. A sample of 50 adolescent smokers and 150 adolescent non-smokers was selected for this study by fixed disease sampling. The dependent variable was current smoking status. The independent variables were cigarette availability, peer-group, family support, pocket money, cigarette advertisement, attitude toward smoking, subjective norm, perceived preventive behavioral control, and intention. The data were collected by a set of questionnaire. The data were analyzed by path analysis.

Results: Smoking behavior was affected by strong intention ( $b=3.7 ; 95 \% \mathrm{CI}=2.5$ to $4.9 ; \mathrm{p}<0.001)$, and weak perceived behavioral control $(\mathrm{b}=3.1 ; 95 \% \mathrm{CI}=1.7$ to $4.5 ; \mathrm{p}<0.001)$. Intention to smoke was affected by weak perceived preventive behavioral control $(\mathrm{b}=2.1 ; 95 \% \mathrm{CI}=1.1$ to $3.2 ; \mathrm{p}<0.001)$, weak preventive subjective norm $(b=1.8 ; 95 \% \mathrm{CI}=0.7$ to $2.9 ; \mathrm{p}=0.001)$, negative attitude $(\mathrm{b}=1.9$; $95 \% \mathrm{CI}=0.8$ to $2.9 ; \mathrm{p}<0.001)$, and exposure to cigarette advertisement $(\mathrm{b}=1.6 ; 95 \% \mathrm{CI}=0.5$ to 2.6 ; $\mathrm{p}=0.004)$. Weak perceived preventive behavioral control was affected by pocket money $\geq \mathrm{Rp}$ $10.000(b=1.3 ; 95 \% \mathrm{CI}=0.5$ to $2.0 ; \mathrm{p}=0.001)$. Weak preventive subjective norm was affected by weak family support $(b=2.1 ; 95 \% \mathrm{CI}=1.3$ to $2.8 ; \mathrm{p}<0.001)$ and smoker peer-group $(\mathrm{b}=1.4 ; 95 \%$ $\mathrm{CI}=0.6$ to $2.1 ; \mathrm{p}<0.001)$. Cigarette advertisement was affected by cigarette availability $(\mathrm{b}=0.7 ; 95 \%$ $\mathrm{CI}=0.1$ to $1.3 ; \mathrm{p}=0.028$ ).

Conclusion: Smoking behavior was directly affected by strong intention and weak perceived behavioral control. Smoking behavior was indirectly affected by weak preventive subjective norm, negative attitude, exposure to cigarette advertisement, pocket money $\geq$ Rp.10.0oo, weak family support, smoker peer-group, and cigarette availability.
\end{abstract}

Keyword: path analysis, smoking behavior, intention, adolescents.

Correspondence: Ardiansyah Pandayu. Master Program in Public Health, Sebelas Maret University, Surakarta. Email: ardiansyahpandayu07@gmail.com. Mobile: +6287864018631.

\section{BACKGROUND}

$\overline{\text { Smoking phenomenon amongst teenagers }}$ has become an everyday occurrence. Smoking behavior for teenagers is a symbolism behavior such as the symbol of appeal, maturity, adulthood, and leadership (Gif- ford et al, 2016). Such behavior could give negative impact on the health and economical aspect (Widiansyah, 2014).

As a global problem, smoking behavior does not only happen in the developed countries but in fact it is higher in the 
developing countries. The number of smokers around the world is 1,2 billion people and 800 million is in developing countries. Increasing cigarettes consumption results in the higher burden of smoke-related diseases and deaths. It is estimated that by 2030, the number of smoke-related deaths would be 10 million lives, and $70 \%$ of which is from developing countries (Kemenkes RI, 2015).

Global Tobacco Epidemic reported in 2013 there was 28 countries with the highest number of smokers in the world. Southeast Asian countries have 325 million teenagers aged between 15-24 years old (WHO, 2010). Global Youth Tobacco Survey in 2014 reported that Indonesia had the highest number of teen smokers in the world. The starting age of teen smokers was around 12-13 years old (42.3\%) (WHO, 2015).

About $34.7 \%$ of Indonesian population age 10 and above were smokers, the prevalence of teen smokers in Indonesia kept on rising every year (Kemenkes RI, 2013a). Surakarta showed that the proportion of smokers every day aged 10 years and over by $18.9 \%$, with the average number of cigarettes (clove, white and handrolled) per day and per week smoked as much as 34.9\% (Kemenkes RI, 2013b).

Smoking behavior is considered an important part of the teenage period (Gifford et al, 2016). Family environment is the main place for children upbringing. Children of smoking parents would most probably also become a smoker in the future Rachmat et al, 2013). Lack of family support is also one of the factors of smoking behavior in teenagers (Mahabee Gittens et al, 2011)

Besides good communication in the family, social economy status or parent's income could also influence teenagers' smoking behavior. The high the parents' income most likely support the child's behavior to use his pocket money to buy cigarettes. Lack of parental supervision towards pocket money expenditure triggers free cigarette purchase due to easy access (Kumar, 2014).

Smoking behavior in teenagers happens because of the access to cigarettes is easily available. The availability of facilities and infrastructure supporting smoking behavior nowadays also caused by consumptive urban lifestyle (Park et al, 2011).

In predicting the risk factor that influenced smoking behavior, Theory of Planned Behavior (TPB) was used. The theory states that behavior is formed because there is the influence of intention determined by three concepts i.e.: attitude, subjective norms, and perceived behavioral control (Ajzen, 1991 cite Droomers et al, 2016).

According to Bandura Social Cognitive Theory (SCT) states that environment, individual, and behavior interact and influencing one another in shaping one's behavior. Smoking habit does not only affected by self-will but also from social environmental factor such as family and peers support (Davies and Macdowall, 2006).

According to Green and Kreuter (2005) healthy behavior is affected by individual as well as environmental factors with model of behavior change PRECEDEPROCEED. Behavior is influenced by 3 main factors, i.e.: predisposing factor, enabling factor and reinforcing factor which are part of the PRECEDE model. Pocket money and access availability to purchase cigarettes influencing teenagers smoking behavior is a part of the enabling factor while the cigarettes advertisement is the reinforcing factor (Fertman, 2010).

Based on the above explanation, thus the researcher was interested to study the influence of personal factors, family support, pocket money, and peers towards teenagers' smoking behavior using theory 
Journal of Health Promotion and Behavior (2017), 2 (2): 98-111

https://doi.org/10.26911/thejhpb.2017.02.02.01

of planned behavior, social cognitive theory and PRECEDE-PROCEED model with path analysis to find out direct and indirect effect on certain risk factors on teenagers smoking behavior in Surakarta.

\section{SUBJECTS AND METHOD \\ 1. Research Design \\ The method of the study was observational analytical study with cross sectional design approach. It was done on February o March 2017 in 5 sub districts in Surakarta regency.}

\section{Population and Sample}

The population of this study was male teenagers in Surakarta. The subject of the study was male teenagers (age 11-24 years old) living in 5 sub districts in Surakarta regency and the election of the subject was as per inclusive criteria. Inclusive criteria of the study was teenagers who were willing to become the respondents of the study, male teenagers aged 11-24 years old, living in Surakarta regency.

Subject collection of the study was confirmed by Fixed disease sampling. The technique was a sampling scheme based on the status of the disease being studied, while subject exposure status varied following the subject's disease status. Fixed disease sampling made sure that there was enough subjects in the case group and control group. From the case group, 50 subjects was taken, and from the control group: 150 subjects.

\section{Research Variables}

The dependent variables was smoking behavior. While the independent variables were cigarettes availability, peers, family support, pocket money, cigarette advertisement, attitude, subjective norms, perceived behavioral control, and intention.

\section{Operational Definition}

Operational definition of cigarette availability is the access or means to facilitate the teenagers to obtain cigarettes, peers are the teenagers' friends who has smoking behaviour, family support is the opinion of the teenagers regarding their parents' behavior and family members who facilitated or hamperred them to have smoking behavior, pocket money is money that comes from the parents or other family members to meet the teenagers' needs, cigarette advertisement is the exposure of the teenagers through different media about cigarette product, attitude is the teenagers' negative or positive opinion related to the facility or difficulty that influenced the teenagers in doing their smoking behavior, subjective norm is the belief that the teenagers felt about the support from their social environment, family members, and peers that influence the teenagers' decision in doing their smoking behavior, perceived behavioral control the teenagers' perception on the ease or difficulty in doing their smoking behavior, intention is will the teenagers have whether they would start smoking or not, smoking behavior is the teenagers' smoking activity or minimum 1 cigarette/ day until the study was done.

\section{Data Analysis}

Data collection technique was using questionnaire filling. The questionnaires consisted of favorable statements (statements about negative things and supportive towards smoking behavior) and unfavorable statements (statements about positive things and unsupportive towards smoking behavior)

\section{Reliability}

The instrument of the study using questionnaires that was tested its validity and reliability as per the result on Table 1 . Smoking availability measured by whether it was available and not. Peers measured by whether they had smoking and non smoking friends. Family support measured whether the support was weak and strong. 
Pandayu et al.,/ Effect of Personal Factors, Family Support, Pocket Money,

Table 1. Reliability test result

\begin{tabular}{lcc}
\hline \multicolumn{1}{c}{ Variable } & Item Total Correlation (r) & Alpha Cronbach \\
\hline Cigarette availability & $\geq 0.66$ & 0.80 \\
Peers & $\geq 0.65$ & 0.93 \\
Family support & $\geq 0.34$ & 0.85 \\
Pocket money & $\geq 0.81$ & 0.90 \\
Cigarette ads & $\geq 0.88$ & 0.94 \\
Attitude & $\geq 0.23$ & 0.86 \\
Subjective norms & $\geq 0.23$ & 0.83 \\
Perceived behavioral control & $\geq 0.33$ & 0.83 \\
Intention & $\geq 0.25$ & 0.90 \\
Smoking behavior & $\geq 0.73$ & 0.99 \\
\hline
\end{tabular}

Tabel 2. Study subject characteristics

Subject Characteristics

Age
$11-14$ year-old
$15-17$ year-old
$18-20$ year-old
$21-24$ year-old

Address

Banjarsari Sub district

Jebres Sub district

Laweyan Sub district

Pasar Kliwon Sub district

Serengan Sub district

Educational level

No school

Primary

Secondary

Senior High School

University (Bachelor)

Father's educational level

Unkown

Primary

Secondary \& High School

University (Bachelor)

Mother's educational level

Unkown

Primary

Secondary \& High School

University (Bachelor)

Father's occupation

Unemployed

Labourer

Entrepreneur

Private employee

Civil Servant

Mother's occupation

Unemployed

Labourer

Entrepreneur

Private Employee

Civil Servant

\section{Smoking Not Smoking}

\begin{tabular}{cccccc}
\hline $\mathbf{n}=50$ & $\%$ & $\mathbf{n}=150$ & $\%$ & $\mathbf{n}=\mathbf{2 0 0}$ & $\%$ \\
\hline
\end{tabular}

10

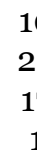

$10 \quad 20.0$

39

65

44.0

$\begin{array}{cc}17 & 34.0 \\ 1 & 2.0\end{array}$

26.0

43.0

24.7

6.0

87

54

24.5

9

20.0

20.0

20.0

20.0

20.0

10

43.5

27.0

5.0

$10 \quad 20.0 \quad 30$

40

20.0

$10 \quad 20.0 \quad 30$

$10 \quad 20.0 \quad 30$

$10 \quad 20.0$

30

6.7

2.0

42.7

38.7

40

20.0

20.0

20.0

40

20.0

$4 \quad 8.0 \quad 10$

$1 \quad 2.0$

3

36.0

64

$19 \quad 38.0$

58

$8 \quad 16.0$

15

10.0

40

7.0

14

4

82

2.0

41.0

38.5

11.5

$\begin{array}{lll}5 & 10.0 & 26\end{array}$

$17 \cdot 3$

$15 \cdot 5$

$7 \quad 14.0$

10.0

11.0

60.7

62.0

$33 \quad 66.0 \quad 91$

12.0

11.5

$\begin{array}{lll}7 & 14.0 & 29\end{array}$

$19 \cdot 3$

0.7

20.7

51.3

22

124

23

18.0

12.0

12.0

31

$\begin{array}{lll}31 & 62.0 & 77\end{array}$

$3 \cdot 3$

32.0

36

1.0

18.5

37

54.0

O 0

0
44.0

5

48

2.5

$10 \quad 20.0$

19

12.7

35.0

$15 \quad 30.0$

44.0

14.5

8.0

$3 \quad 6.0 \quad 12$

54.7

19.3

11.3

12.0

2.7

4

$107 \quad 53.5$

$\begin{array}{lllll}11 & 22.0 & 29 & 40 & 20.0\end{array}$

$\begin{array}{llllll}8 & 12.5 & 17 & 11.3 & 25 & 12.5\end{array}$

$6 \quad 12.0$

24

12.0

2.0

4

2.0 
Journal of Health Promotion and Behavior (2017), 2 (2): 98-111

https://doi.org/10.26911/thejhpb.2017.02.02.01

Pocket money was measured by how high $\geq$ Rp. 10.000 and low < Rp. 10.000. Cigarette advertisement measured by whether or not they were exposed by the advertisement. Attitude measured by positive and negative smoking attitude. Subjective norms measured by strong and weak subjective norms. Perceived behavioral control perception measured by strong and weak perceived behavioral control. Intention measured by strong and weak smoking intention. Smoking behavior measured by not smoking behavior and smoking behavior.

The analysis used in the study was path analysis. Path analysis is an analysis technique used to find the influence a certain exogenous variable towards a certain endogenous variable whether directly or indirectly. The size of free variables (exogenous) towards attached variables (endogenous) could be seen from the path coefficient value, the larger the coefficient the bigger the influence given by the variable.

Steps in data analysis with path analysis were model specification, model identification, parameter estimation, and model respecification.

\section{A. Univariate Analysis}

\section{RESULTS}

The study was done in five sub districts in Surakarta regency i.e.: Banjarsari, Jebres, Laweyan, Pasar Kliwon, and Serengan sub districts with 10 teen smokers and 30 non smoking teens each.

Table 2 showed that the age proportion of teen smoker were at the highest at the age of 15-17 years old with as many as 22 smokers (44\%) and non smoking teen proportion at the age of $15-17$ years old as many as 65 teens (43\%). Most of the teenagers had senior high school education as many 19 teens (38\%) while the non smoking teenagers were mostly had junior high school education as many as 64 teens (42.7\%).

The teenagers parents' (father and mother) educational level was divided into five categories of no school, elementary school, junior high school, senior high school, and university (bachelor degree/S1). The highest proportion of parents of smoking teens was on junior and senior high school level as many as 33 fathers (66\%) and 31 mothers (62\%), the same thing happened for parents of non smoking teenagers that most of them had junior and senior high school education as many as 91 fathers (60.7\%) and 77 mothers (51.3\%).

Parents (fathers and mothers) of the teenagers occupation were divided into five categories, i.e: jobless, laborer, entrepreneur, employee, and civil servant. The type of occupation of the smoking teenagers were mostly as laborer fathers as many as 22 (44\%) respondents and jobless (housewife) mothers of $25(50 \%)$ respondents while the type of parents occupation of non smoking teenagers were mostly as employee fathers as many as 66 respondents (44\%) and jobless (housewife) mothers as many as $82(54.7 \%)$ respondents .

\section{B. Bivariate Analysis}

Based on table 3, it showed the influence amongst cigarettes availability, peers, family support, pocket money, cigarettes advertisement, attitude, subjective norms, behavior control perception, and intention towards smoking behavior of the teenagers in Surakarta.

On the cigarette availability variable, about $34.1 \%$ teenagers had access to it while 93.8\% non smoking teenagers did not have access to cigarettes availability. Analysis result using Chi Square testing showed that there was meaningful relation between cigarettes availability and teenagers smoking behavior with the $\mathrm{p}<0.001$ and $\mathrm{OR}=7.9$ (CI 95\% $=2.7$ to 23.0). 
On the peers variable, about 55.3\% smoking teenagers also had smoking peers while $93.5 \%$ of the non smoking peers did not have smoking peers. The analysis result with Chi Square testing showed that there was a meaningful relation between peers and teenagers smoking behavior with the $\mathrm{p}$ $<0.001$ and $\mathrm{OR}=17.9$ (CI 95\%= 7.7 to 41.8).

On the family support variable, about 78.6\% smoking teenagers had weak family support while the non smoking teenagers had $95.8 \%$ strong family support. The analysis result with Chi Square testing showed that there was a meaningful relation between family support and teenagers' smoking behavior with the $\mathrm{p}=<0.001$ and $\mathrm{OR}=$ 84.3 (CI $95 \%=29.9$ to 237.9 ).

On the pocket money variable, $32.7 \%$ of the smoking teenagers got $\geq$ Rp. 10.000 pocket money while $96.2 \%$ of the non smoking teenagers got $<\mathrm{Rp} .10 .000$ pocket money. The analysis test result with Chi Square testing showed that there was a meaningful relation between pocket money and teenagers smoking behavior with the $\mathrm{p}=<0.001$ and $\mathrm{OR}=12.4(\mathrm{CI} 95 \%=2.9$ to 52.9).

On the cigarette advertisement variable, about $44.8 \%$ smoking teenagers exposed by the advertisement while $90.3 \%$ of the non smoking teenagers did not get exposure. The analysis result with Chi Square testing showed meaningful relation between cigarettes advertisement and teenagers smoking behavior with the $\mathrm{p}=<0.001$ and $\mathrm{OR}=7.5$ (CI 95\%= 3.6 to 15.9 ).

On the attitude variable, there was
$67.2 \%$ of the smoking teenagers that had negative attitude while there was $96.2 \%$ of the non smoking teenagers that had positive attitude. The analysis result with $C h i$ Square testing showed that there was a meaningful relation between attitude and teenagers smoking behavior with the $\mathrm{p}=$ $<0.001$ and $\mathrm{OR}=52.4(\mathrm{CI} 95 \%=18.7$ to 146.5).

On the subjective norm variable, there was $62.3 \%$ of the smoking teenagers had weak subjective norms while $94.7 \%$ of the non smoking teenagers have strong subjective norms. The analysis test result with Chi Square testing showed that there was meaningful relation between subjective norms and teenagers smoking behavior with the $\mathrm{p}=<0.001$ and $\mathrm{OR}=29.3$ (CI 95\%= 11.9 to 72.3$)$. On the behavior control perception, about $61.8 \%$ of the smoking teenagers had weak behavior control perception, while $97.6 \%$ of the non smoking teenagers had strong behavior control perception. The analysis result with Chi Square testing showed that there was meaningful relation between behavior control perception and teenagers smoking behavior with the $\mathrm{p}<0.001$ and $\mathrm{OR}=65.4$ (CI 95\%= 19.0 to 224.9).

On the intention variable, there was $77.6 \%$ of the smoking teenagers had strong intention, whereas there was $96.5 \%$ of the non smoking teenagers with weak intention. The analysis result with Chi Square testing showed that there was meaningful relation between intention and teenagers smoking behavior with the $\mathrm{p}=<0.001$ and $\mathrm{OR}=94.8(\mathrm{CI} 95 \%=32.0$ to 280.7$)$. 
Journal of Health Promotion and Behavior (2017), 2 (2): 98-111

https://doi.org/10.26911/thejhpb.2017.02.02.01

Table 3. Bivariate analysis result on cigarettes availability, peers, family support, pocket money, cigarettes ad, attitude, subjective norms, behavior control perception, and intention towards smoking behavior of the teens in Surakarta

\begin{tabular}{|c|c|c|c|c|c|c|c|c|c|}
\hline \multirow{3}{*}{ Variable } & \multicolumn{4}{|c|}{ Smoking Status } & \multirow{2}{*}{\multicolumn{2}{|c|}{ Total }} & \multirow{3}{*}{ OR } & \multirow{3}{*}{ CI (95\%) } & \multirow{3}{*}{$\mathbf{p}$} \\
\hline & \multicolumn{2}{|c|}{ Smoking } & \multicolumn{2}{|c|}{$\begin{array}{c}\text { Not } \\
\text { Smoking }\end{array}$} & & & & & \\
\hline & $\mathbf{n}$ & $\%$ & $\mathbf{n}$ & $\%$ & $\mathbf{N}$ & \% & & & \\
\hline \multicolumn{10}{|l|}{ Cigarette availability } \\
\hline Yes & 46 & 34.1 & 89 & 65.9 & 135 & 100 & 7.9 & $2.7-23.0$ & $<0.001$ \\
\hline No & 4 & 6.2 & 61 & 93.8 & 65 & 100 & & & \\
\hline \multicolumn{10}{|l|}{ Peers } \\
\hline Yes & 42 & $55 \cdot 3$ & 34 & 44.7 & 76 & 100 & 17.9 & $7.7-41.8$ & $<0.001$ \\
\hline No & 8 & 6.5 & 116 & 93.5 & 124 & 100 & & & \\
\hline \multicolumn{10}{|l|}{ Family Support } \\
\hline Weak & 44 & 78.6 & 12 & 21.4 & 56 & 100 & 84.3 & $29.9-237.9$ & $<0.001$ \\
\hline Strong & 6 & 4.2 & 138 & 95.8 & 144 & 100 & & & \\
\hline \multicolumn{10}{|l|}{ Pocket Money } \\
\hline High ( $\geq$ Rp.10.ooo) & 48 & 32.7 & 99 & $67 \cdot 3$ & 147 & 100 & 12.4 & & $<0001$ \\
\hline Low (<Rp.10.000) & 2 & 3.8 & 51 & 96.2 & 53 & 100 & & $2.9-52.9$ & $<0.001$ \\
\hline \multicolumn{10}{|l|}{ Cigarettes ad } \\
\hline Yes & 39 & 44.8 & 48 & 55.2 & 87 & 100 & $7 \cdot 5$ & $3.6-15.9$ & $<0.001$ \\
\hline No & 11 & 9.7 & 102 & 90.3 & 113 & 100 & & & \\
\hline \multicolumn{10}{|l|}{ Attitude } \\
\hline Negative & 45 & 67.2 & 22 & 32.8 & 67 & 100 & 52.4 & $18.7-146.5$ & $<0.001$ \\
\hline Positive & 5 & 3.8 & 128 & 96.2 & 133 & 100 & & & \\
\hline \multicolumn{10}{|l|}{ Subjektive Norm } \\
\hline Weak & 43 & 62.3 & 26 & 37.7 & 69 & 100 & 29.3 & $11.9-72.3$ & $<0.001$ \\
\hline Strong & 7 & $5 \cdot 3$ & 124 & 94.7 & 131 & 100 & & & \\
\hline \multicolumn{10}{|l|}{ Behavior Control } \\
\hline \multicolumn{10}{|l|}{ Perception } \\
\hline Weak & 47 & 61.8 & 29 & 38.2 & 76 & 100 & 65.4 & $19.0-224.9$ & $<0.001$ \\
\hline Strong & 3 & 2.4 & 121 & 97.6 & 124 & 100 & & & \\
\hline \multicolumn{10}{|l|}{ Intention } \\
\hline Strong & 45 & 77.6 & 13 & 22.4 & 58 & 100 & 94.8 & $32.0-280.7$ & $<0.001$ \\
\hline Weak & 5 & 3.5 & 137 & 96.5 & 142 & 100 & & & \\
\hline
\end{tabular}

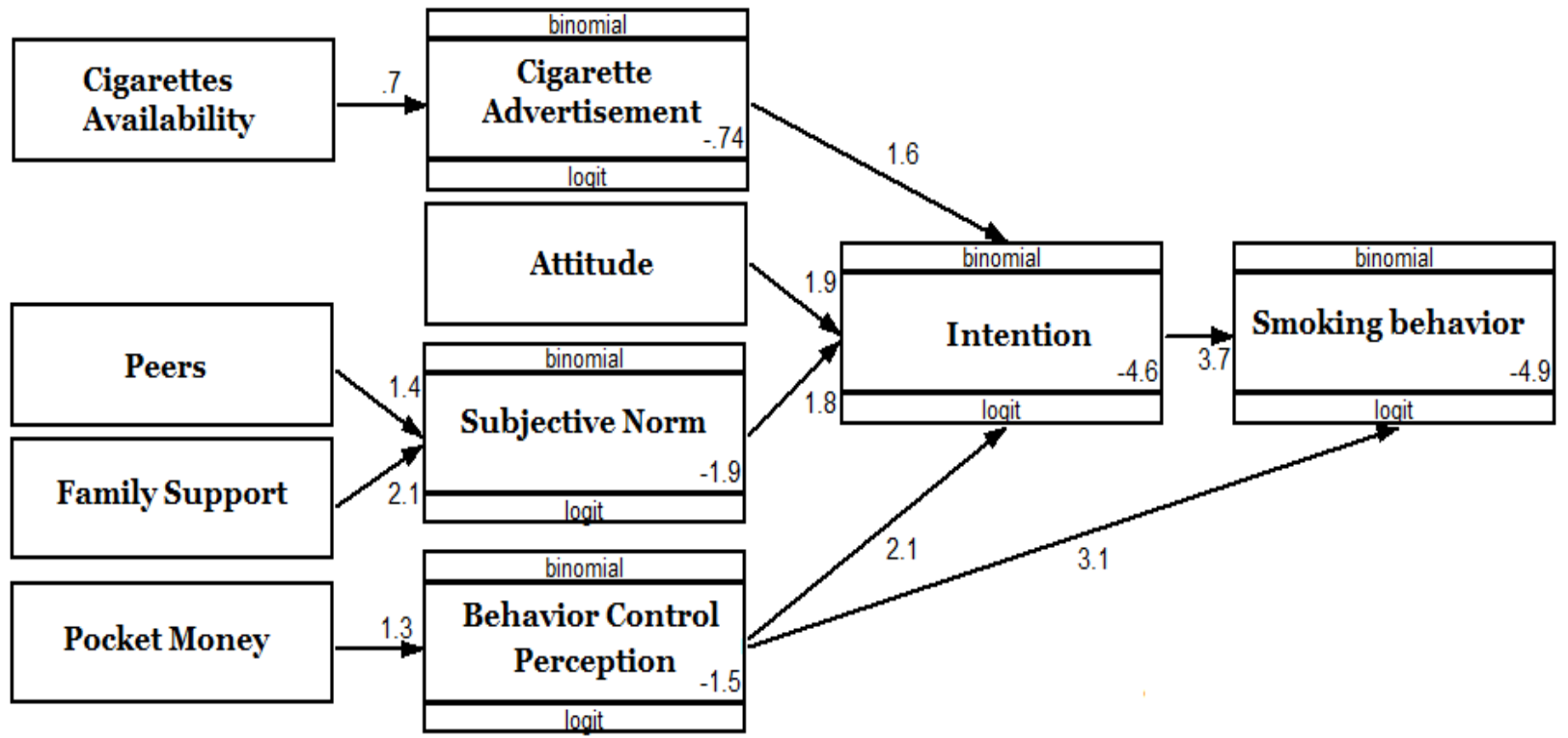

Picture 1. Structural model with estimation 
Pandayu et al.,/ Effect of Personal Factors, Family Support, Pocket Money,

Table 4. Path analysis test result on personal, family support, pocket money, and peers towards teenagers' smoking behavior on the teenagers in Surakarta.

\begin{tabular}{|c|c|c|c|c|}
\hline \multirow[b]{2}{*}{ Variable } & \multirow{2}{*}{$\begin{array}{c}\text { Line } \\
\text { Coefficient } \\
\text { (b) }\end{array}$} & \multicolumn{2}{|c|}{ CI 95\% } & \multirow[b]{2}{*}{$\mathbf{p}$} \\
\hline & & $\begin{array}{c}\text { Lower } \\
\text { limit }\end{array}$ & $\begin{array}{c}\text { Upper } \\
\text { limit }\end{array}$ & \\
\hline \multicolumn{5}{|l|}{ Smoking behavior } \\
\hline Strong smoking intention & 3.7 & 2.5 & 4.9 & $<0.001$ \\
\hline Weak perceived behavioral control & 3.1 & 1.7 & 4.5 & $<0.001$ \\
\hline \multicolumn{5}{|l|}{ Intention } \\
\hline Cigarette ads exposure & 1.6 & 0.5 & 2.6 & 0.004 \\
\hline Negative attitude & 1.9 & 0.8 & 2.9 & $<0.001$ \\
\hline Weak subjective norms & 1.8 & 0.7 & 2.9 & 0.001 \\
\hline Weak perceived behavioral control & 2.1 & 1.1 & 3.2 & $<0.001$ \\
\hline \multicolumn{5}{|l|}{ Perceived behavioral control } \\
\hline Pocket money $\geq$ Rp. 10.000 & 1.3 & 0.5 & 2.0 & 0.001 \\
\hline \multicolumn{5}{|l|}{ Subjective Norms } \\
\hline Smoking peers & 1.4 & 0.6 & 2.1 & $<0.001$ \\
\hline Weak family support & 2.1 & 1.3 & 2.8 & $<0.001$ \\
\hline \multicolumn{5}{|l|}{ Cigarette advertisement } \\
\hline Cigarette availability & 0.7 & 0.1 & 1.3 & 0.028 \\
\hline
\end{tabular}

\section{Multivariate Analysis}

Table 4 showed the influence of intention towards smoking behavior and the result was significant. Teenagers with strong intention had log odd 3.7 more to smoke than the teenagers with wear intention (CI 95\%= 2.5 to $4.9 ; \mathrm{p}=<0.001$ ).

There was perceived behavioral control towards smoking behavior and the result was significant. Teenagers with weak perceived behavioral control had log odd 3.1 more than teenagers with strong perceived behavioral control (CI 95\% $=1.7$ to $4.5 ; \mathrm{p}=<0.001$ ).

There was the influence of perceived behavioral control towards intention and the result was significant. Teenagers with weak perceived behavioral control had log odd to smoke 2.1 more than teenagers with strong perceived behavioral control (CI $95 \%=1.1$ to $3.2 ; \mathrm{p}=<0.001$ ).

There was the influence of subjective norm towards intention and the result was significant. Teenagers with weak subjective norm had log odd to smoke 1.8 more than teenagers with strong subjective norm (CI $95 \%=0.7$ to $2.9 ; \mathrm{p}=0.001$ ).

There was the influence of attitude toward intention and the result was sig- nificant. Teenagers with negative attitude had log odd to smoke 1.9 more than the teenagers with positive attitude (CI 95\%= 0.8 to $2.9 ; \mathrm{p}=<0.001$ ).

There was the influence of cigarette advertisement towards the intentions and the result was significant. Teenagers exposed to the advertisement had log odd 1.6 more than teenagers that did not get a lot of exposure (CI 95\%=0.5 to $2.6 ; \mathrm{p}=0.004$ ).

There was the influence of pocket money towards perceived behavioral control and the result was significant. Teenagers with more pocket money had log odd to smoke 1.3 more than teenagers with low pocket money (CI $95 \%=0.5$ to $2.0 ; \mathrm{p}=$ o.001).

There was the influence of family support towards subjective norms and the result was significant. Teenagers with weak family support had log odd 2.1 bigger than teenagers with strong family support (CI $95 \%=1.3$ to $2.8 ; \mathrm{p}=<0.001$ ).

There was the influence of peers towards subjective norms and the result was significant. Teenagers with smoking peers had log odd to smoke 1.4 bigger than teenagers that did not have smoking peers (CI $95 \%=0.6$ to $2.1 ; \mathrm{p}=<0.001$ ). 
Journal of Health Promotion and Behavior (2017), 2 (2): 98-111

https://doi.org/10.26911/thejhpb.2017.02.02.01

There was the influence of cigarette availability towards cigarette advertisement and the result was significant. Teenagers with access to cigarette availability had log odd to smoke 0.7 more than teenagers that did not have access to cigarette availability (CI $95 \%=0.1$ to $1.3 ; \mathrm{p}=0.028$ ).

\section{DISCUSSION}

1. The influence of Intention in the smoking behavior of Teenagers in Surakarta.

This study showed that intention had an influence in the smoking behavior. Supported by the study done by Park et al, (2011) that showed the relation between the intention of smoking with smoking behavior on Korean-Chinese teenagers.

The smoking intention is the strongest predictor in turning someone into a smoker. This is caused by the nicotine in the cigarette that makes the teenagers keeps on smoking (Zhong et al, 2016). On the teenagers in Iran, the high intention in smoking causes them to have the smoking behavior caused by the belief that smoking can help boosting their popularity and controlling their emotions. (Mohammadpoorasl et al, 2012).

This study was supported by the Theory of Planned Behavior (TPB) stated by Azjen that intention is formed by attitude toward behavior, subjective norms, and perceived behavioral control each individual have. These three will interact and would determine whether the intention will be carried out or not (Azwar, 2013).

2. The Influence of perceived behavioral control towards the smoking behavior in the teenagers in Surakarta.

The result of the study showed that there is a relation between the perceived behavioral control with the smoking behavior. The perceived behavioral control has an impor- tant role on the smoking behavior to happen. A weak perceived behavior control would increase the teenagers' urge to smoke. The intention to smoke could happen because there is a "role model" to the smoking behavior, where personal and social factor hold important position through perceived behavioral control. (Wiium et al, 2006).

The study is supported by the Theory of Planned Behavior (TPB) stated by Ajzen where the perceived behavioral control is a dimension of self control where an individual feel in relation to faith on how far they could express the behavior out. (Barmpagianni et al, 2013). The decision making and self-control are the important factors in deciding the smoking behavior in teenagers (Finigan-Carr et al, 2015).

3. The influence of perceived behavioral control towards intention to the smoking behavior of the teenagers in Surakarta.

The result of the study showed that there is a relation between perceived behavioral control with intention. The perceived behavior control is the best predictor on the intention to have smoking behavior (Topa and Moriano, 2010). A teenager would think that smoking behavior is something normal, fun, and profitable, they tend to have the urge to try because they feel like they could, thus making the intention to smoke stronger and formed the smoking behavior to the teenager (Hamda, 2015).

This study is supported by the Theory of Planned Behavior (TPB) stated by Ajzen that any intention is formed by one of the concepts which is the perceived behavioral control each individual has. This causing the teenagers with weak behavioral control to think thatn smoking is something normal and therefore strengthen his intention to try smoking and make the smoking behavior. 
4. The influence of subjective norms through the intention on the smoking behavior on teenagers in Surakarta.

The result of the study showed that there is an influence from subjective norms with the intention. This is supported by the study done by Ganley and Rosario (2013) using the Theory of Planned behavior that shows that there is a relation between subjective norms with the smoking behavior of teenagers in the United States.

This influenced is due to the intention to smoke. Subjective norms could predict and explain one's intention to start their smoking behavior (Talip et al, 2016b). A teenager would not start smoking if the perceived behavior control in their social environment is strong against cigarette. If not, weak control from the social environment could increase the urge to smoke (Talip et al, 2016b).

This study is supported the Theory of Planned Behavior that stated that each behavior is molded by the influence of strong intention from within and decided by one of the concepts which is the subjective norms. This explained that if there is any social environment that supported the behavior, the teenagers would be more susceptible to the smoking behavior (Ajzen, 1991 cite Blankers et al, 2016)

5. The influence of the attitude towards smoking behavior through the teenagers attitude in Surakarta.

The result of the study showed that there is an influence between intention and attitude. Based on the study by Karimy et al, 2012 in Iran that the attitude influences the intention to start smoking because of the low knowledge the teenagers have when it comes to the dangerous effect of smoking to their health, besides that they also does not believe that smoking behavior could risk their health. Therefore, the negative attitude that supported the smoking behavior supported the teenagers to have the intention to keep smoking. The attitude became the strongest predictor on the intention to the smoking behavior on teenagers (Karimy et al, 2012).

This study supported the Theory of Planned Behavior that stated that the behavior is formed because of a strong intention within oneself and decided by one of the concepts which is attitude. This is made the teenagers tend to have an idea supporting the smoking behavior so that they have the intention to keep on smoking (Ajzen, 1991 cite Blankers et al, 2016).

6. The influence of cigarette advertisement towards the smoking behavior through the teenagers intention in Surakarta

This result of the study showed that there is a relation between intention and the influence of the advertisement. This is supported by the study done by Rachmat et al, 2013 that stated the relation between cigarette advertisement with the smoking behavior on the teenagers in Makassar. The advertisement as a promotional media is potential in building the teenagers smoking behavior and attitude. This is caused by the apparent intention to smoke. Any exposure of to the advertisement is related to the smoking behavior and the intention to do so (Rachmat et al, 2013).

The exposure to cigarette advertisement is related to the rising of smoking intention for the teenagers. The image promoted by the advertisement they have, whether on the billboard or in the television gives a positive connotation thus indirectly increasing the teenagers' idea that smoking is something "interesting", "modern", "fun" and "trendy" and causing them the have the tendency to have the smoking behavior (Dereje et al, 2014).

This study supported the PRECEDEPROCEED (Reinforcing factor) that ex- 
Journal of Health Promotion and Behavior (2017), 2 (2): 98-111

https://doi.org/10.26911/thejhpb.2017.02.02.01

plained how the exposure to cigarette advertisement could strengthen their decision to have the intention to smoke (Prabandari and Dewi, 2016).

7. The influence of pocket money towards the smoking behavior through perceived behavioral control in the teenagers in Surakarta.

The result of the study showed that there is a relation between the influence of pocket money with perceived behavioral control. Teenagers with a higher amount of pocket money tend to support their smoking behavior. The high amount of pocket money due to the parents bigger income increases the teenager's risk to smoke (Heo et al, 2014).

Lack of parental control on the teenagers' pocket money triggered the free cigarette purchase due to its easy access (Kumar, 2014). This influence could also happen because of the perceived behavioral control, in which the uncontrolled pocket money could increase the teenagers' confidence to spend it to their liking, including to buy cigarette (Heo et al, 2014).

This study was supported by the PRECEDE-PROCEED (enabling factor) model that explained that by the availability of any facility like pocket money will support the forming of a behavior, especially the smoking behavior (Park et al, 2011; Hughes et al, 2010).

\section{The influence of family support towards subjective norms on the smoking behavior in the teenagers in Surakarta.}

The result of the study showed that the family support influenced the subjective norms. The family could influence the smoking behavior, whether through unharmonious parental situation, overly authoritative parents, lack of communication with the parents, and family with smoking parents because they are the role model for the kids (Aula, 2010).
The influence could be caused by the subjective norms, where the social environmental support like family support becomes the reason of a smoking teenager (Scalici and Schulz, 2017). Parental point of view will form the child's behavior, this could encourage the urge to smoke. The weak family support like the lack of open communication and the lack of respect could also become the strengthening factor in the smoking behavior among teenagers (Mahabee-Gittens et al, 2011).

This study was supported by the social cognitive theory that the lack of social environmental support like family support could become a causing factor of smoking behavior among teenagers. Teenagers coming from troublesome families with history of bad behavior, negligence, lack of attention on control from the parents would find it easier to smoke compared to their peers from harmonious household (Du et al, 2015; Bird et al, 2016).

9. The influence of peers towards smoking behavior through the subjective norms in the teenagers in Surkarta.

The result of the study showed that the peers influenced the subjective norms. The needs to be accepted often made teenagers willing to do anything including to smoke, to get accepted with their peer group (Shadid and Hossain, 2013).A study by Scalici and Schulz (2017) found that teenagers acted based on what they see in their social environmant, especially on copying their peers.

The study was supported by the social cognitive theory that stated that the smoking behavior is not only because of an individual's willingness but also can be caused by the social environment factor like peers (Davies and Macdowall, 2006; Joung et al, 2016). 
10. The influence of the cigarette availability towards smoking behavior through cigarette advertisement in teenagers in Surakarta.

The result of the study showed that there was an influence of cigarette availability with the cigarette ad. Access availability to cigarette selling is due to the lack of age limit on cigarette selling, supported by the the seller' ignorance on the buyers' age. Therefore, they could increase the smoking behavior among teenagers (Hughes et al, 2010).

This influence is caused by the exposure to the cigarette ad. This could be seen through the high number of cigarette advertisement media used to promote their products, such as road billboards and posters where they sell them (Prabandari and Dewi, 2016; Ford et al, 2016). The advertisement is a possible factor that could encourage the smoking behavior among teenagers (Dereje et al, 2014).

This study supported the PRECEDEPROCEED (enabling factor) theory that stated that the cigarette availability is a mean to support and encourage the teenagers to have the smoking behavior (Park et al, 2011; Hughes et al, 2010).

The study concluded that the smoking behavior is influenced by intention and perceived behavioral control. The intention is influenced by perceived behavioral control, subjective norms, attitude and cigarette advertisement. Perceived behavioral control is influenced by the pocket money. Subjective norms are influenced by family support and peers. The cigarette advertisement is influenced by the product availability.

\section{REFERENCE}

Aula EL (2010). Stop Smoking (Sekarang atau Tidak Sama Sekali). Yogyakarta: Garailmu.
Azwar S (2013). Sikap Manusia Teori dan Pengukurannya. Edisi 2. Yogyakarta: Pustaka Pelajar.

Barmpagianni E, Travlos A, Kalokairinou A, Sachlas A, Zyga S (2013). Investigation of Aggravating Psychosocial Factors on Health and Predictability of Smoking and Alcohol Use in Post Adolescent Students. Health chology Research 1(2): 15.

Bird Y, Staines-Orozco H, Moraros J (2016). Adolescents' smoking experiences, family structure, parental smoking and socio-economic status in Ciudad Juárez, Mexico. International Journal for Equity in Health 15(29).

Blankers M, Buisman R, Hopman P, Van Gool R, Van Laar M (2016). Modelling Intentions to Provide Smoking Cessation Support Among Mental Health Professionals in The Netherlands. Tobacco Induced Diseases 14(1): 32.

Davies M, Macdowall W (2006). Health Promotion Theory. New York. Open University Press.

Dereje N, Abazinab S, Girma A (2014). Prevalence and Predictors of Cigarette Smoking among Adolescents of Ethiopia: School Based Cross Sectional Survey. Journal Child Adolescent Behavior 3(182): 1-8.

Droomers M, Huang X, Fu W, Yang Y, Li H, Zheng $P$ (2016). Educational disparities in the intention to quit smoking among male smokers in China: a cross-sectional survey on the explanations provided by the theory of planned behaviour. BMJ Open 6(10).

Ebrahimi H, Sahebihagh MH, Ghofranipour F, Tabrizi JS (2014). Initiation and Continuation of Smoking in Iran: A Qualitative Content Analysis. IJCBNM 2(4): 220-230. 
Journal of Health Promotion and Behavior (2017), 2 (2): 98-111

https://doi.org/10.26911/thejhpb.2017.02.02.01

Fertman CI,Allensworth DD (2010). Health

Promotion Programs. USA: Jossey Bass.

Finigan-Carr NM, Cheng TL, Gielen A, Haynie DL, Simons-Morton B (2015). Using the Theory of Planned Behavior to Predict Aggression and Weapons Carrying in Urban African American Early Adolescent Youth. Health education \& behavior 42(2): 220-230.

Ford A, MacKintosh AM, Bauld L, Moodie C, Hastings G (2016). Adolescents' responses to the promotion and flavouring of e-cigarettes. Int $\mathrm{J}$ Public Health (61): 215-224.

Ganley BJ, Rosario DI (2013). The smoking attitudes, knowledge, intent, and behaviors of adolescents and young adults: Implications for nursing practice. Journal of Nursing Education and Practice 3(1).

Gifford H, Tautolo E, Erick S, Hoek J, Gray R, Edwards R (2016). A Qualitative Analysis of Maori And Pacific Smokers Views on Informed Choice and Smoking. BMJ Open.

Gwon, Hyun S, Jeong, Suyong (2016). Factors Influencing Adolescent Life time Smoking and Current Smoking in South Korea: Using data from the 10th (2014) Korea Youth Risk Behavior Web-Based Survey. J Korean Acad Nurs 46(4): 552-561.

Hamdan SR (2015). Pengaruh Peringatan Bahaya Rokok Bergambar pada Intensi Berhenti Merokok. Mimbar 3(1): 241-250.

Heo J, Oh J, Subramanian SV, Kawachi I (2014). Household and School-Level Influences on Smoking Behavior among Korean Adolescents: A Multilevel Analysis. Shahab L, ed. PLoS ONE 9(6).

Hohman ZP, Crano WD, Siegel JT, Alvaro EM (2014). Attitude Ambivalence,
Friend Norms, and Adolescent Drug Use. Prev Sci 15(1): 65-74.

Hughes SK, Hughes K, Atkinson AM, Bellis MA, Smallthwaite L (2010). Smoking behaviours, access to cigarettes and relationships with alcohol in 15 and 16-year-old schoolchildren. European Journal of Public Health 21(1): 8-14.

Joung MJ, Han MA, Park J, Ryu SY (2016). Association between Family and Friend Smoking Status and Adolescent Smoking Behavior and E-Cigarette Use in Korea. International Journal of Environmental Reseach and public Health 13(12): 1183.

Karimy M, Niknami S, Hidarnia AR, Hajizadeh I (2012). Intention to start cigarette smoking among Iranian male adolescents: usefulness of an extended version of the theory of planned behaviour. Heart Asia. 4(1).

Kemenkes RI (2013a). Riset Kesehatan Dasar Indonesia. Badan Penelitian Dan Pengembangan Kesehatan. Jakarta: Kemenkes RI.

Kemenkes RI (2013b). Riset Kesehatan Dasar Dalam Angka Provinsi Jawa Tengah 2013. Badan Penelitian dan Pengembangan Kesehatan. Jakarta: Kemenkes RI.

Kemenkes RI (2015). InfoDatin: Perilaku Merokok Masyarakat Indonesia. Jakarta: Kemenkes RI.

Kumar V, Talwar R, Roy N, Raut D, Singh S (2014). Psychosocial Determinants of Tobacco Use among School Going Adolescents in Delhi, India. Journal of Addiction.

Mahabee-Gittens E, Khoury J, Huang B, Dorn L, Ammerman R (2011). The Protective Influence of Family Bonding on Smoking Initiation in Adolescents by Racial/Ethnic and Age Subgroups. Journal of Child and Adolescent Substance Abuse. 
Mohammadpoorasl A, Nedjat S, Yazdani K, Fakhari A, Foroushani AR, Fotouhi A (2012). Intention to Start Smoking and its Related Factors in Never Smoked Adolescents in Tabriz, 2010. International Journal of Preventive Medicine 3(12): 880-886.

Park SE, Yoon SN, Yi Y, Cui W, Nam B (2011). Prevalence and risk factors of adolescents smoking: difference between korean and korean-chinese. Asian Nursing Research 5(3): 189-95.

Prabandari YS, Dewi A (2016). How do Indonesian youth perceive cigarette advertising? A cross-sectional study among Indonesian high school students. Glob Health Action (9): 30914.

Rachmat M, Thaha RM, Syafar M (2013). Perilaku Merokok Remaja Sekolah Menengah Pertama. Jurnal Kesehatan Masyarakat Nasional 7(11): 502-508.

Scalici F, Schulz PJ (2017). Parents' and peers' normative influence on adolescents' smoking: results from a SwissItalian sample of middle schools students. Substance Abuse Treatment, Prevention, and Policy.

Shadid HM, Hossain SZ (2013). Understanding Smoking Behaviour among Secondary School Students in Amman, Jordan: A Qualitative Study. J Community Med Health Educ.

Talip T, Murang Z, Kifli N, Naing L (2016b). Systematic Review of Smoking Initiation among Asian Adoles- cents, 2005-2015: Utilizing the Frameworks of Triadic Influence and Planned Behavior. Asian Pacific Journal of Cancer Prevention 17(7).

Topa G, Moriano JA (2010). Theory of planned behavior and smoking: metaanalysis and SeM model. Department of Social and Organizational Psychology, UNeD, Madrid, Spain. Substance Abuse and Rehabilitation. Dovepress.

WHO (2010). Brief Profile On Gender and Tobacco in South-East Asia Region India. New Delhi: WHO-SEARO.

WHO (2015), Regional Office for SouthEast Asia. Global Youth Tobacco Survey (GYTS): Indonesia report. New Delhi: WHO-SEARO.

Widiansyah M (2014). Faktor-Faktor Penyebab Perilaku Remaja Perokok Di Desa Sidorejo Kabupaten Penajam Paser Utara. E-Journal Sosiologi 2(04): 1-12.

Wiium N, Breivik K, Wold B (2006). The Relationship between Smoker Role Models and Intentions to Smoke among Adolescents. Journal of Youth and Adolescence 35(4).

Zhong J, Cao S, Gong W, Fei F, Wang M (2016). Electronic Cigarettes Use and Intention to Cigarette Smoking among Never-Smoking Adolescents and Young Adults: A Meta-Analysis. International Journal of Environment. Research and Public Health 13(465). 